\title{
Applications of Cell-Free Fetal DNA in Maternal Serum
}

\author{
Saeid Ghorbian
}

\begin{abstract}
Cell-free fetal DNA (cffDNA) is available in the maternal circulation throughout pregnancy and can be used for noninvasive prenatal diagnosis including, determination of fetal sex, identification of specific single gene disorders, typing of fetal blood groups (RhD), paternity determination and potentially routine use for Down's syndrome (DS) testing of all pregnancies. I searched published literature on the PubMed and databases on Scopus interface systematically using keyword's cffDNA, noninvasive diagnosis, fetal DNA in the maternal serum. Reference lists from the papers were also searched. cffDNA representing only $3 \%$ of the total cell-free circulating DNA in early and rising to $12 \%$ in late pregnancy, clinical investigations has already demonstrated the potential advantage, such as improving safety, earlier diagnosis and comparative ease of testing using cffDNA technology. The discovery of cffDNA circulating in the maternal serum has opened the door to noninvasive prenatal diagnosis testing with novel clinical implications.
\end{abstract}

Keywords: Cell-free fetal DNA, Noninvasive testing, Prenatal diagnosis.

How to cite this article: Ghorbian S. Applications of Cell-Free Fetal DNA in Maternal Serum. Int J Infertility Fetal Med 2012;3(2):33-39.

Source of support: Nil

Conflict of interest: None declared

\section{INTRODUCTION}

In 1997, Lo et al identified cell-free fetal DNA (cffDNA) in the maternal serum circulation. This recommendation has generated research in the development of clinical applications based on evaluating of cffDNA for noninvasive diagnosis. ${ }^{1}$ Nonetheless, invasive techniques of prenatal diagnosis, such as amniocentesis, cordocentesis and chorionic villus sampling (CVS), are precious and correlated with risks to the mother and the fetus; these procedures carry a risk of miscarriage of around $1 \%{ }^{2,3}$ Advances in molecular genetic have provided new tools for the genetic analysis of cffDNA isolated from maternal serum. ${ }^{4}$ The cffDNA originates in trophoblast cells, therefore, fetal DNA fragments are released into maternal circulation after trophoblast degradation; apoptosis of fetal cells circulating in maternal blood may provide a minor source of cffDNA $^{5-7}$ and comprises around 3 to $6 \%$ of the total cffDNA in maternal circulation during early and late pregnancy respectively. ${ }^{8}$ However, currently with development of

Date of Received: 02-02-12

Date of Acceptance: 16-02-12

Date of Publication: May 2012 approaches, such as microfluidics digital polymerase chain reaction (PCR), reveals a higher than expected concentrations of fetal DNA around 10 to $12 \%$ of total DNA in maternal plasma. ${ }^{9}$ The size of circulating cffDNA predominantly of short DNA fragments, 193 base pairs in length ${ }^{10}$ and can be detected from the 4 weeks of gestation, ${ }^{11}$ though only reliably from 7 weeks, and the concentration increases with gestational age with a sharp peak during the last 8 weeks of pregnancy. ${ }^{8,12}$ The half-life of cffDNA is 16 minutes and is undetectable 2 hours after delivery, therefore, rapidly cleared from the maternal circulation. ${ }^{13}$ cffDNA may be detectable for several days. ${ }^{14}$ Significantly, more fetal DNA is presence in maternal circulation during pregnancy as compared with the fetal DNA extracted from the cellular fraction of maternal blood. ${ }^{15}$

\section{INVASIVE AND NONINVASIVE PRENATAL SCREENING TESTS}

Current prenatal diagnosis relies on a combination of techniques, which falls into two categories: Noninvasive and invasive prenatal screening tests which are designed to detect those cases, which have a higher probability of fetal abnormality. There are many forms of prenatal diagnosis which are currently in use, such as amniocentesis and CVS, are invasive diagnostic techniques which are most widely accepted methods for obtaining fetal cells for genetic analysis. Both of these techniques are invasive and carry an associated risk of approximately $1 \%$ fetal loss. ${ }^{16}$ Noninvasive techniques are used as screening tools and lack the predictive power to form diagnostic tests individually. Ultrasound examinations are routinely used to diagnose congenital defects, such as Down's syndrome. Maternal serum screening for fetal biomarkers is another noninvasive method for the measurement of fetal-specific proteins as an indicator for trisomy $21 .{ }^{17}$ There are new technologies for the isolation of fetal cells from maternal blood. ${ }^{18}$ After the discovery of fetal cells, it has been hypothesized that fetal nucleic acids may well also circulate in the maternal bloodstream. The presence of cffDNA in the maternal circulation was first discovered, by identification of a $\mathrm{Y}$ chromosome-specific sequence SRY. ${ }^{1}$

\section{PRESENCE OF cffDNA IN THE MATERNAL CIRCULATION}

The potential use of cffDNA in plasma or serum was first developed as a tool for molecular diagnosis of tumor DNA 
has been detected in the cancer patients. ${ }^{19}$ The placenta has been well characterized as an invasive tissue. ${ }^{20}$ Based on the hypothesis that the placenta has some cancer-like properties, therefore, we can be identifying cffDNA in the circulation of pregnant women. If cffDNA could be identified and isolated from maternal peripheral blood samples, it could potentially be used in prenatal screening of fetal anomalies. Use of cffDNA technology within existing specialist, clinical genetic services provide a valuable tool for earlier and safer determination of fetal sexlinked disorders. However, the availability of noninvasive tests using cffDNA could also lead to an increase to the ability in prenatal diagnosis testing and could influence the choices by parents to continue or terminations of pregnancy. ${ }^{21}$

\section{ORIGIN OF cffDNA IN MATERNAL CIRCULATION}

Fetal DNA originates from trophoblasts derived from the embryo $^{22}$ and representing only $3 \%$ of the total cell-free circulating DNA in early pregnancy rising to $6 \%$ in late pregnancy. ${ }^{8}$ It is proposed that apoptosis is the main route by which stable DNA is released by cells into the circulation. ${ }^{5}$ However, the precise mechanism of DNA release may also include the release of DNA by normal healthy lymphocytes. ${ }^{23}$ Three possibilities mechanism discussed of DNA release: Fetal hematopoietic cells, the placenta and direct transfer of DNA molecules. ${ }^{24}$

\section{CLINICAL APPLICATIONS FOR cffDNA}

The majority of current investigations attended on cffDNA in the maternal circulation for clinical trials, specifically using quantitative real-time polymerase chain reaction amplification (Q-PCR) assays for prenatal screening ${ }^{25}$ and diagnosis of various pregnancy-associated disorders, including preeclampsia, ${ }^{26-28}$ preterm labor ${ }^{29,30}$ and fetal trisomy $21 .{ }^{31}$ In addition, by using reverse transcriptase polymerase chain reaction (RT-PCR), sex-linked disorders, sex determination ${ }^{32-34}$ the $\mathrm{RhD}$ status of fetuses, ${ }^{35}$ and single gene disorders, such as $\beta$-thalassemia, ${ }^{36,37}$ congenital adrenal hyperplasia ${ }^{38}$ and achondroplasia can be detected. ${ }^{39}$ The main limitation at present appears to be the availability of uniquely fetal gene sequences that identify and measure the presence of fetal DNA in both male and female fetuses.

\section{FETAL SEX AND SEX-LINKED GENETIC DISORDERS DETERMINATION}

There are extensively potential implementations for which cffDNA can be used for noninvasive prenatal diagnosis. The first application is the determination of fetal sex, by revealing genes instant on the $\mathrm{Y}$ chromosome in male fetuses. It must detect the sex-determining region Y (SRY), although a number of other $\mathrm{Y}$ chromosome-specific sequences present in multiple copies (DYS, DYZ and DAZ) per male genome have also been investigated. ${ }^{40-42}$ This has been shown to be accurate at around 7 weeks or later gestation. ${ }^{43}$ Fetal sexing can be used to consider risk for certain sex-linked hereditary disorders. Hemophilia is an $\mathrm{X}$ chromosome-linked familial disease, where males are affected with defective blood clotting factors, and females are carriers of the disease, therefore, optional choices at the parents to continue or terminations of pregnancy. ${ }^{44}$ Fetal sex determination can also help in diagnosis, where there is genital obscurity, and in the management of metabolic conditions. ${ }^{45}$ Several studies have demonstrated that there is a diagnostic sensitivity of $100 \%$ at 7 and 5 weeks of gestation using conventional and real-time PCR Table $1{ }^{46-57}$

\section{RhD GENOTYPING}

The application cffDNA is a definition of fetal RhD blood group status in RhD-negative women, by detecting the paternally inherited $\mathrm{RhD}$ gene. This assessment supplies the basis for management of anti-D immunoglobulin as prophylaxis in pregnancies, where the fetus is confirmed as

\begin{tabular}{|c|c|c|c|c|}
\hline Author/years & Gestation (weeks) & Gene & Accuracy (\%) & Specificity (\%) \\
\hline Lo et al $(1997)^{48}$ & $12-40$ & SRY & 80 & 100 \\
\hline Sekizawa et al (2001) $)^{49}$ & $7-16$ & DYS14 & 100 & 97.2 \\
\hline Honda et al (2002) & $5-10$ & DYS14 & 100 & 100 \\
\hline Guibert et al $(2003)^{51}$ & $4-9$ & SRY & 100 & 100 \\
\hline Rijnders et al (2004) ${ }^{52}$ & $11-19$ & SRY & 97.2 & 100 \\
\hline Hyett et al $(2005)^{53}$ & $7-14$ & SRY & 100 & 100 \\
\hline Davalieva et al (2006) $)^{54}$ & 16 & SRY & 100 & 89.2 \\
\hline Bustamante et al (2008) ${ }^{55}$ & 17 & SRY & 100 & 100 \\
\hline Akolekar et al $(2010)^{56}$ & $11-13$ & SRY & 99.84 & - \\
\hline \multirow[t]{4}{*}{ Stephanie et al $(2011)^{57}$} & $<7$ & SRY & - & 99.1 \\
\hline & $7-12$ & & - & 98.9 \\
\hline & $13-20$ & & - & 99.1 \\
\hline & $>20$ & & - & 99.6 \\
\hline
\end{tabular}


$\mathrm{RhD}^{+}$and the mother is $\mathrm{RhD}{ }^{58}$ The detection of $\mathrm{RhD}^{+}$ sequences can be used to predict fetal RhD status also by traditional or by real-time PCR. However, numerous and extensive studies have been published regarding the determination of fetal RhD status from cffDNA in Table 2. ${ }^{52,59-65}$ This is significant for the prevention of fetal hemolytic disease, where an $\mathrm{RhD}^{-}$mother becomes sensitized to an $\mathrm{RhD}^{+}$fetus, which stimulates a maternal immune response to produce IgG anti-D antibodies, which are able to cross the placenta and destroy fetal blood cells, giving increase to fetal anemia and jaundice. ${ }^{35}$ In the Caucasian population, the $\mathrm{RhD}^{-}$phenotype is generated by a deletion within the RhD gene, whereas in over $80 \%$ of the African population, the phenotype is caused by a nonfunctional copy of the RhD gene, $\mathrm{RhD} \psi$ the $\mathrm{RhD}$ pseudo gene. Using a PCR appraisal for exons 4, 5 and 6, it is practicable to discriminate $\mathrm{RhD}^{-}$from $\mathrm{RhD} \psi$, which enables detection of all $\mathrm{RhD}^{-}$cases with $100 \%$ accuracy and provides the basis of the noninvasive test for RhD. ${ }^{66}$

\section{DETECTING OF SINGLE-GENE DISORDERS}

The diagnosis-specific single gene disorders in families with a high-risk of an transmissible disorder, such as achondroplasia, Huntington's, myotonic dystrophy, congenital adrenal hyperplasia, hemophilia and $\beta$-thalassemia disease, frequently caused by a single-point mutation, requires the identification of changed genes in maternal circulation and can currently only be done to detect a gene alteration that is not present in the mother. ${ }^{67}$

Achondroplasia is an autosomal dominant disorder, caused by point mutations within the FGFR3 gene, which accounts for more than $98 \%$ of the cases involved has been detected using cffDNA. ${ }^{68}$ Huntington's disease appears to be a true Mendelian dominant because homozygote and heterozygote expressions are similar, generally associated with impressive changes in the area of the CAG trinucleotide repeats. Identification of Huntington's disease status was demonstrated to be highly accurate as early as 10 weeks of gestational age, although test sensitivity was reduced with greater expansion of CAG trinucleotide repeats. ${ }^{69-71}$
Myotonic dystrophy is an autosomal dominant disorder, associated with the changeable extension of a CTG trinucleotide repeat in the 3'untranslated region (3'-UTR) of the DM KINASE gene. In one study, paternally received expanded alleles revealed cffDNA in the maternal circulation. ${ }^{72}$ Adrenal congenital, a group of recessive situations, resulted in enhanced production of androgens. It is detectable of intragenic polymorphic markers in intron 2 of the CYP21 gene. Using the analysis of fetal DNA in maternal blood can be detected recessive mutation congenital adrenal hyperplasia. ${ }^{73} \beta$-Thalassemia is a recessive blood disorder, caused by mutations in the globins' genes on chromosome 11 resulting in modifications to either the structure or production of hemoglobin, leading to chronic anemia. ${ }^{74}$ A noninvasive experiment has also been advanced for $\beta$-thalassemia major. The assessment is based on a PCR assay designed to detect a paternally inherited CTTT deletion within the gene, which is the most conventional mutational cause of $\beta$-thalassemia. Allele-specific real-time PCR can be applied to mutations for $\beta$-thalassemia with $100 \%$ sensitivity and near-perfect specificity. ${ }^{36,75}$ Recently, Tsui et al by using the digital relative mutation dosage (RMD) approach recognized specifically genotypes of fetal that received a hemophilia mutation on chromosome $\mathrm{X}$ in plasma samples acquired at-risk carrying offspring women from as early as 11 weeks of gestation. ${ }^{76}$

\section{ANEUPLOIDY IDENTIFICATION}

Inaccuracies throughout the meiosis can begin aneuploidies, producing a number of gametes to gain a supplementary chromosome and change into trisomic. Attention has focused on aneuploidy, which is a notable cause of reproductive failure and congenital disease with unique remark to common chromosome disorders, such as trisomy 21 Down, trisomy 13 Patau and trisomy 18 Edward's syndromes as well as the sex chromosome aneuploidies XXY Klinefelter's, XYY, XXX, and X0 Turner's syndromes. ${ }^{77}$ The most conventional invasive prenatal diagnostic technique for any aneuploidy is supplied by CVS

Table 2: Some of the studies that were evaluated with Rh genotyping using cffDNA

\begin{tabular}{|c|c|c|c|}
\hline Author/years & Gestation (weeks) & Specificity (\%) & Sensitivity (\%) \\
\hline Rijinders et al (2004) $)^{52}$ & $11-19$ & 96.6 & 100 \\
\hline Brojer et al $(2005)^{59}$ & $5-39$ & 98.6 & 100 \\
\hline Machado et al (2006) ${ }^{60}$ & $4-41$ & 93.8 & 98.3 \\
\hline Rouillac-Le Sciellour et al $(2007)^{61}$ & $10-34$ & 97.5 & 100 \\
\hline Minon et al $(2008)^{62}$ & $10-38$ & 99.5 & 100 \\
\hline Cardo et al $(2010)^{63}$ & $9-13$ & 100 & 93 \\
\hline Bombard et al (2011) (cohort 1) $)^{64}$ & $6-30$ & 98.3 & 100 \\
\hline Bombard et al (2011) (cohort 2) & $11-13$ & 96.8 & 97.2 \\
\hline Tounta et al $(2011)^{65}$ & $7-24$ & 96.7 & 100 \\
\hline
\end{tabular}


or amniocentesis followed by karyotyping, although more recently, the easiest process of detecting an aneuploidy is to evaluate the relative amount of the target chromosome by selecting a region located on the chromosome and amplifying it by real-time PCR assay, and juxtaposing the product with that of other regions on different chromosome. $^{78}$ The majority common known aneuploidy consistent with life is Down's syndrome (DS). It was first characterized by Langdon Down in 1866 and linked to trisomy 21 in 1959 by Lejeune and Jacobs. ${ }^{79}$ It is the largest part common chromosomal abnormality resulting in learning difficulties and mental defects. There is no racial predisposition, males and females are influenced in the almost the same ratios. ${ }^{80}$

Several studies have declared that the levels of cffDNA heightened in aneuploidy conditions. ${ }^{81}$ For example, in the DS pregnancies, cffDNA level increased of a 1.7-fold higher than to the serum controls. ${ }^{82}$ Recently, Lo et al reported the use of multiplex massively parallel sequencing of cffDNA in maternal plasma detected trisomy 21 fetuses with 100\% sensitivity and $97.9 \%$ specificity. ${ }^{83}$

In another study, Chiu et al demonstrated the clinical effectiveness and practical feasibility of high-throughput DNA sequencing of singular chromosome 21 sequences in maternal serum with $79.1 \%$ sensitivity and $98.9 \%$ specificity. $^{84}$

Additional aneuploidies with recognized clinical significance consist of trisomy 18 and 13, both of which are frequently fatal within the first few months of life. Contemporary noninvasive approaches of prenatal diagnosis involve the use of screening technologies and procedures in order to evaluate risk of fetal aneuploidy, such as those based on ultrasound, the detection of serum biomarkers and at the finally using cffDNA can greatly reduce the number of pregnancies, which are subjected to testing by invasive methods. ${ }^{85}$ Notwithstanding maternal serum cffDNA levels are increased in cases of trisomy 13 , but not in trisomy $18 .^{86}$

The other applications of cffDNA could be the paternity determinate of the fetus, by detection of systems DNA-STR (short tandem repeat) genotyping. The DNA-STR mostly has multiple alleles and can have high levels of diversity; that is, high heterozygosity. The systems DNA-STR genotyping is a standard for forensics and paternity testing. ${ }^{87,88}$

\section{CONCLUSION}

The analysis of cffDNA in maternal serum and plasma is an operational region of research. The probability is that there will be a significant change in how we counsel women and couples who are considering prenatal screening and genetic diagnosis. The outstanding advantages of using
cffDNA over conventional techniques of prenatal diagnosis are that the sampling method is noninvasive and, therefore, raises no risk to mother or child, and it can be pregnancy management. The relative ease of measurement of cffDNA levels in maternal plasma and serum has led to clinical applications to the detection of fetal aneuploidy, sex, $\mathrm{Rh}$ genotype and some single-gene disorders. Novel approaches, such as using microarray technology that is already available it is not difficult to imagine that amplified fetal nucleic acids will ultimately permit a noninvasive fetal genome to scan as part of routine prenatal screening. Moreover, the researcher's trends to progression clinical applications through the using of cffDNA, but implicated by several limitation's assessments in this field, including (a) the low concentrations of maternal serum cffDNA levels in earlier stage of gestation, (b) the occurrence of falsenegative/positive results in $\mathrm{Rh}$ genotyping and sex determination of the fetus, especially to the twin-gestation, (c) situations where both parents carry a mutant allele for recessively inherited monogenic disorders or for the diagnosis of fetal aneuploidy is more challenging and invasive prenatal diagnosis plays a crucial role here. Nevertheless, we hope that development in the new technologies will be capable in overcoming these limitations.

\section{ACKNOWLEDGMENT}

The author thanks Dr David Gaze et al from Clinical Sciences Review Committee (CSRC) for critical reading of the manuscript and providing helpful comments.

\section{ABBREVIATIONS}

cffDNA: Cell-free fetal DNA; 3'-UTR: 3'untranslated region; CVS: Chorionic villus sampling; RT-PCR: Reverse transcriptase polymerase chain reaction; SRY: Sex determining region of Y chromosome; DS: Down's syndrome.

\section{REFERENCES}

1. Lo YM, Corbetta N, Chamberlain PF, Rai V, Sargent IL, Redman CW, Wainscoat JS. Presence of fetal DNA in maternal plasma and serum. Lancet 1997;350:485-87.

2. Walknowska J, Conte FA, Grumbach MM. Practical and theoretical implications of fetal-maternal lymphocyte transfer. Lancet 1969;1119-22.

3. Mujezinovic F, Alfirevic Z. Procedure-related complications of amniocentesis and chorionic villous sampling: A systematic review. Obstet Gynecol 2007;110:687-94.

4. Bianchi DW, Williams JM, Sullivan LM, Hanson FW, Klinger KW, Shuber AP. PCR quantitation of fetal cells in maternal blood in normal and aneuploid pregnancies. Am J Hum Genet 1997;61:822-29. 
5. Alberry M, Maddocks D, Jones M, et al. Free fetal DNA in maternal plasma in anembryonic pregnancies: Confirmation that the origin is the trophoblast. Prenat Diagn 2007;27: 415-18.

6. Sekizawa A, Yokokawa K, Sugito Y, et al. Evaluation of bidirectional transfer of plasma DNA through placenta. Hum Genet 2003;113:307-10.

7. Wataganara T, Metzenbauer M, Peter I, Johnson KL, Bianchi DW. Placental volume, as measured by 3-dimensional sonography and levels of maternal plasma cell-free fetal DNA. Am J Obstet Gynecol 2005;193:496-500.

8. Lo YM, Tein MS, Lau TK, et al. Quantitative analysis of fetal DNA in maternal plasma and serum: Implications for noninvasive prenatal diagnosis. Am J Hum Genet 1998;62:768-75.

9. Lun FMF, Chiu RWK, Chan KCA, Leung TY, Lau TK, Lo YMD. Microfluidics digital PCR reveals a higher than expected fraction of fetal DNA in maternal plasma. Clin Chem 2008;54:1664-72.

10. Chan KC, Zhang J, Hui AB, et al. Size distributions of maternal and fetal DNA in maternal plasma. Clin Chem 2004;50:88-92.

11. Illanes S, Denbow M, Kailasam C, Finning K, Soothill PW. Early detection of cell-free fetal DNA in maternal plasma. Early Hum Dev 2007;83:563-66.

12. Birch L, English CA, O’Donoghue K, Barigye O, Fisk NM, Keer JT. Accurate and robust quantification of circulating fetal and total DNA in maternal plasma from 5 to 41 weeks of gestation. Clin Chem 2005;51:312-20.

13. Lo YM, Leung TN, Tein MS, et al. Quantitative abnormalities of fetal DNA in maternal serum in preeclampsia. Clin Chem 1999;45:184-88.

14. Wataganara T, Chen AY, LeShane ES, et al. Cell-free fetal DNA levels in maternal plasma after elective first-trimester termination of pregnancy. Fertil Steril 2004;81:638-44.

15. Lo YM. Fetal DNA in maternal plasma: Biology and diagnostic applications. Clin Chem 2000;46:1903-06.

16. Brambati B, Tului L. Chorionic villus sampling and amniocentesis. Curr Opin Obstet Gynecol 2005;17:197-201.

17. Cuckle HS, van Lith JM. Appropriate biochemical parameters in first-trimester screening for Down syndrome. Prenat Diagn 1999;19:505-12.

18. Weier JF, Weier HU, Jung CJ, et al. Human cytotrophoblasts acquire aneuploidies as they differentiate to an invasive phenotype. Dev Biol 2005;279:420-32.

19. Kawakami K, Brabender J, Lord RV, et al. Hypermethylated APC DNA in plasma and prognosis of patients with esophageal adenocarcinoma. J Natl Cancer Inst 2000;92:1805-11.

20. Fisher SJ, Cui TY, Zhang L, et al. Adhesive and degradative properties of human placental cytotrophoblast cells in vitro. J Cell Biol 1989;109:891-902.

21. Amicucci P, Gennarelli M, Novelli G, Dallapiccola B. Prenatal diagnosis of myotonic dystrophy using fetal DNA obtained from maternal plasma. Clin Chem 2000;46:301-02.

22. Tjoa ML, Cindrova-Davies T, Spasic-Boskovic O, Bianchi DW, Burton GJ. Trophoblastic oxidative stress and the release of cellfree feto-placental DNA. Am J Pathol 2006;169:400-04.

23. Wright CF, Burton $\mathrm{H}$. The use of cell-free fetal nucleic acids in maternal blood for non-invasive prenatal diagnosis. Hum Reprod Update 2009;15:139-51.

24. Anker P, Stroun M. Immunological aspects of circulating DNA. Ann NY Acad Sci 2006;1075:34-39.

25. Bianchi DW. Circulating fetal DNA: Its origin and diagnostic potential—a review. Placenta 2004;25 (Suppl A):S93-101.
26. Cotter AM, Martin CM, O’Leary JJ, Daly SF. Increased fetal DNA in the maternal circulation in early pregnancy is associated with an increased risk of preeclampsia. Am J Obstet Gynecol 2004;191:515-20.

27. Zhong XY, Gebhardt S, Hillermann R, Tofa KC, Holzgreve W, Hahn S. Parallel assessment of circulatory fetal DNA and corticotropin-releasing hormone mRNA in early- and late-onset preeclampsia. Clin Chem 2005;51:1730-33.

28. Zhong XY, Holzgreve W, Gebhardt S, et al. Minimal alteration in the ratio of circulatory fetal DNA to fetal corticotropinreleasing hormone mRNA level in preeclampsia. Fetal Diagn Ther 2006;21:246-49.

29. Leung TN, Zhang J, Lau TK, Hjelm NM, Lo YM. Maternal plasma fetal DNA as a marker for preterm labour. Lancet 1998;352:1904-05.

30. Shimada K, Murakami K, Shozu M, Segawa T, Sumitani H, Inoue M. Sex-determining region $\mathrm{Y}$ levels in maternal plasma: Evaluation in abnormal pregnancy. J Obstet Gynaecol Res 2004;30:148-54.

31. Tong YK, Lo YM. Diagnostic developments involving cell-free (circulating) nucleic acids. Clin Chim Acta 2006;363: 187-96.

32. Costa JM, Benachi A, Gautier E. New strategy for prenatal diagnosis of X-linked disorders. N Engl J Med 2002; 346:1502.

33. Clausen FB, Krog GR, Rieneck K, et al. Antenatal determination of fetal RhD-blood type based on fetal DNA in plasma from the RhD-negative mother-secondary publication. Ugeskr Laeger 2006;168:2568-70.

34. Brojer E, Zupanska B, Guz K, Orzinska A, Kalinska A. Noninvasive determination of fetal RHD status by examination of cell-free DNA in maternal plasma. Transfusion 2005;45: 1473-80.

35. Van der schoot CE, Soussan AA, koalevijn AA. Noninvasive antenatal RhD typing. Trarsfus Clin Biol 2006;13:53-57.

36. Chiu RW, Lau TK, Leung TN, Chow KC, Chui DH, Lo YM. Prenatal exclusion of beta-thalassaemia major by examination of maternal plasma. Lancet 2002;360:998-1000.

37. Li Y, Di Naro E, Vitucci A, Zimmermann B, Holzgreve W, Hahn S. Detection of paternally inherited fetal point mutations for beta-thalassemia using size-fractionated cell-free DNA in maternal plasma. JAMA 2005;293:843-49.

38. Chiu RW, Lau TK, Cheung PT, Gong ZQ, Leung TN, Lo YM. Noninvasive prenatal exclusion of congenital adrenal hyperplasia by maternal plasma analysis: A feasibility study. Clin Chem 2002;48:778-80.

39. Saito H, Sekizawa A, Morimoto T, Suzuki M, Yanaihara T. Prenatal DNA diagnosis of a single-gene disorder from maternal plasma. Lancet 2000;356:1170.

40. Zimmermann B, El-Sheikhah A, Nicolaides K, Holzgreve W, Hahn S. Optimized real-time quantitative PCR measurement of male fetal DNA in maternal plasma. Clin Chem 2005;51:15981604.

41. Deng $\mathrm{Z}, \mathrm{Wu} \mathrm{G}, \mathrm{Li}$ Q, et al. Noninvasive genotyping of 9 Y-chromosome specific STR loci using circulatory fetal DNA in maternal plasma by multiplex PCR. Prenat Diagn 2006;26: 362-68.

42. Stanghellini I, Bertorelli R, Capone L, et al. Quantitation of fetal DNA in maternal serum during the first trimester of pregnancy by the use of a DAZ repetitive probe. Mol Hum Reprod 2006;12:587-91. 
43. Hyett JA, Gardener G, Stojilkovic-Mikic T, et al. Reduction in diagnostic and therapeutic interventions by non-invasive determination of fetal sex in early pregnancy. Prenat Diagn 2005;25:1111-16.

44. Santacroce R, Vecchione G, Tomaiyolo M, et al. Identification of fetal gender in maternal blood is a helpful tool in the prenatal diagnosis of haemophilia. Haemophilia 2006;12:417-22.

45. Newson AJ. Ethical aspects arising from non-invasive fetal diagnosis. Semin Fetal Neonatal Med 2008;13:103-08.

46. Rijnders RJ, van der Schoot CE, Bossers B, de Vroede MA, Christiaens GC. Fetal sex determination from maternal plasma in pregnancies at risk for congenital adrenal hyperplasia. Obstet Gynecol 2001;98:374-78.

47. Bianchi DW. Prenatal exclusion of recessively inherited disorders: Should maternal plasma analysis precede invasive techniques? Clin Chem 2002;48:689-90.

48. Lo YM, Corbetta N, Chamberlain PF, et al. Presence of fetal DNA in maternal plasma and serum. Lancet 1997;350:385-87.

49. Sekizawa A, Kondo T, Iwasaki M, et al. Accuracy of fetal gender determination by analysis of DNA in maternal plasma. Clin Chem 2001;47:1856-58.

50. Honda H, Miharu N, Ohashi Y, Ohama K. Successful diagnosis of fetal gender using conventional PCR analysis of maternal serum. Clin Chem 2001;47:41-46.

51. Guibert J, Benachi A, Grebille AG, Ernault P, Zorn JR, Costa JM. Kinetics of SRY gene appearance in maternal serum: Detection by real time PCR in early pregnancy after assisted reproductive technique. Hum Reprod 2003;18:1733-36.

52. Rijnders RJP, Christiaens CML, Soussan AA, Van der Schoot CE. Cell-free fetal DNA is not present in plasma of nonpregnant mothers. Clin Chem 2004;50:678-79.

53. Hyett JA, Gardiner G, Stojilkovic-Mikic T, et al. Reduction in diagnostic and therapeutic interventions by non-invasive determination of fetal sex in early pregnancy. Prenat Diagn 2005;25:1111-16.

54. Davalieva K, Dimcev P, Efremov GD, Plaseska-Karanfilska D. Non-invasive fetal sex determination using real-time PCR. J Matern Fetal Neonatal Med 2006;19:337-42.

55. Bustamante AA, Rodriguez de AM, Gonzalez GC, et al. Foetal sex determination in maternal blood from the seventh week of gestation and its role in diagnosing haemophilia in the foetuses of female carriers. Haemophilia 2008;14:593-98.

56. Akolekar R, Farkas DH, VanAgtmael AL, Bombard AT, Nicolaides KH. Fetal sex determination using circulating cellfree fetal DNA (ccffDNA) at 11 to 13 weeks of gestation. Prenat Diagn 2010;30:918-23.

57. Devaney Stephanie A, Palomaki Glenn E, Scott Joan A, Bianchi Diana W. Noninvasive fetal sex determination using cell-free fetal DNA A systematic review and meta-analysis. JAMA 2011;306:627-36.

58. Sekizawa A, Purwosunu Y, Matsuoka R, Koide, et al. Recent advances in non-invasive prenatal DNA diagnosis through analysis of maternal blood. J Obstet Gynaecol Res 2007;33: 747-64.

59. Brojer E, Zupanska B, Guz K, Orziñska A, Kaliñska A. Noninvasive determination of fetal RHD status by examination of cell-free DNA in maternal plasma. Transfusion 2005;45: 1473-80.

60. Machado IN, Castilho L, Pellegrino J Jr, Barini R. Fetal rhd genotyping from maternal plasma in a population with a highly diverse ethnic background. Rev Assoc Med Bras 2006;52: 232-35.
61. Rouillac LC, Sérazin V, Brossard Y, et al. Noninvasive fetal RHD genotyping from maternal plasma. Use of a new developed free DNA fetal kit RhD. Transfus Clin Biol 2007;14: 572-77.

62. Minon JM, Gerard C, Senterre JM, Schaaps JP, Foidart JM. Routine fetal RHD genotyping with maternal plasma: A four-year experience in Belgium. Transfusion 2008;48: 373-81.

63. Cardo L, García BP, Alvarez FV. Non-invasive fetal RHD genotyping in the first trimester of pregnancy. Clin Chem Lab Med 2010;48:1121-26.

64. Bombard AT, Akolekar R, Farkas DH, et al. Fetal RHD genotype detection from circulating cell-free fetal DNA in maternal plasma in non-sensitized RhD negative women. Prenat Diagn 2011;31: 802-08.

65. Tounta G, Vrettou C, Kolialexi A, et al. A multiplex PCR for non-invasive fetal RHD genotyping using cell-free fetal DNA. In Vivo 2011;25:411-17.

66. Finning KM, Martin PG, Soothill PW, Avent ND. Prediction of fetal D status from maternal plasma: Introduction of a new noninvasive fetal RhD genotyping service. Transfusion 2002;42: 1079-85.

67. Li Y, Page-Christiaens GC, Gille JJ, Holzgreve W, Hahn S. Non-invasive prenatal detection of achondroplasia in sizefractionated cell-free DNA by MALDI-TOF MS assay. Prenat Diagn 2007;27:11-17.

68. Saito H, Sekizawa A, Morimoto T, Suzuki M, Yanaihara T. Prenatal DNA diagnosis of a single-gene disorder from maternal plasma. Lancet 2000;356:1170.

69. Gonzalez MC, Trujillo MJ, Rodriguez AM, et al. Huntington disease-unaffected fetus diagnosed from maternal plasma using QF-PCR. Prenat Diagn 2003;23:232-34.

70. Gonzalez MC, Trujillo MJ, Rodriguez AM, Ramos C. Early Huntington disease prenatal diagnosis by maternal semiquantitative fluorescent-PCR. Neurol 2003;60:1214-15.

71. Bustamante-AA, Trujillo MJ, Gallego MJ, et al. Prenatal diagnosis of Huntington disease in maternal plasma: Direct and indirect study. Eur J Neurol 2008;15:1338-44.

72. Amicucci P, Gennarelli M, Novelli G, Dallapiccola B. Prenatal diagnosis of myotonic dystrophy using fetal DNA obtained from maternal plasma. Clin Chem 2000;46:301-02.

73. Chiu RW, Lau TK, Cheung PT, Gong ZQ, Leung TN, Lo YM. Noninvasive prenatal exclusion of congenital adrenal hyperplasia by maternal plasma analysis: A feasibility study. Clin Chem 2002;48:778-80.

74. Johnston TA. Haemoglobinopathies in pregnancy. Obstet Gynecol 2005;7:149-57.

75. Nasis O, Thompson S, Hong $\mathrm{T}$, et al. Improvement in sensitivity of allele-specific PCR facilitates reliable noninvasive prenatal detection of cystic fibrosis. Clin Chem 2004;50: 694-01.

76. Nancy BY, Tsui RA, Kadir KC, et al. Noninvasive prenatal diagnosis of hemophilia by microfluidics digital PCR analysis of maternal plasma DNA. Blood 2011;31:117.

77. Hall A, Bostanci A, Wright CF. Non-invasive prenatal diagnosis using cell-free fetal DNA technology: Applications and implications. Publ Heal Genom 2010;13:246-55.

78. Hassold T, Hunt P. To err (meiotically) is human: The genesis of human aneuploidy. Nat Rev Genet 2001;2:280-91.

79. Down JL. Observations on an ethnic classification of idiots. 1866 Ment Retard 1995;33:54-56. 
80. Wapner RJ. Invasive prenatal diagnostic techniques. Semin Perinatol 2005;29:401-04.

81. Lo YM, Lau TK, Zhang J, et al. Increased fetal DNA concentrations in the plasma of pregnant women carrying fetuses with trisomy 21. Clin Chem 1999;45:1747-51.

82. Lee T, LeShane ES, Messerlian GM, et al. Down syndrome and cell-free fetal DNA in archived maternal serum. Am J Obstet Gynecol 2002;187:1217-21.

83. Lo YM, Lun FM, Chan KC, et al. Digital PCR for the molecular detection of fetal chromosomal aneuploidy. Proc Natl Acad Sci USA 2007;104:13116-21.

84. Chiu RW, Akolekar R, Zheng YW, et al. Non-invasive prenatal assessment of trisomy 21 by multiplexed maternal plasma DNA sequencing: Large scale validity. BMJ 2011;342:c7401.

85. Byard RW. Forensic issues in Down syndrome fatalities. J Forensic Leg Med 2007;14:475-81.
86. Wataganara T, LeShane ES, Farina A, et al. Maternal serum cell free fetal DNA levels are increased in cases of trisomy 13 but not trisomy 18. Hum Genet 2003;112:204-08.

87. Tong YK, Ding C, Chiu RW, et al. Noninvasive prenatal detection of fetal trisomy 18 by epigenetic allelic ratio analysis in maternal plasma: Theoretical and empirical considerations. Clin Chem 2006;52:2194-02.

88. Budowle B, Masibay A, Anderson SJ, et al. STR primer concordance study. Forensic Sci Int 2001;124:47-54.

\section{ABOUT THE AUTHOR}

\section{Saeid Ghorbian}

Department of Biology, Bonab Branch, Islamic Azad University, Iran e-mail: ghorbian20@yahoo.com 